\title{
IMPACTS OF CLIMATE CHANGE ON LEPIDOPTERA SPECIES AND COMMUNITIES
}

\author{
KoCSIS, M. ${ }^{1 *}$ - HUfNAGEL, L. ${ }^{2}$ \\ ${ }^{I}$ Department of Management and Marketing, Corvinus University of Budapest \\ H-1118 Budapest, Villányi út 29-43, Hungary \\ (phone: +36-1-482-6171; fax: +36-1-482-6331) \\ 2 "Adaptation to Climate Change" Research Group of the Hungarian Academy of Sciences - \\ Corvinus University of Budapest \\ H-1118 Budapest, Villányi út 29-33, Hungary \\ (phone: +36-1-482-6261; fax: +36-1-466-9273) \\ *Corresponding author \\ e-mail:marton.kocsis@uni-corvinus.hu \\ (Received $17^{\text {th }}$ December 2010; accepted $28^{\text {th }}$ January 2011)
}

\begin{abstract}
In this review, the impacts of climate change on Lepidoptera species and communities are summarized, regarding already registered changes in case of individual species and assemblies, and possible future effects. These include changes in abundance, distribution ranges (altitude above sea level, geographical distribution), phenology (earlier or later flying, number of generations per year). The paper also contains a short description of the observed impacts of single factors and conditions (temperature, atmospheric $\mathrm{CO}_{2}$ concentration, drought, predators and parasitoids, UV-B radiation) affecting the life of moths and butterflies, and recorded monitoring results of changes in the Lepidoptera communities of some observed areas. The review is closed with some theoretical considerations concerning the characteristics of "winner" species and also the features and conditions needed for a successful invasion, conquest of new territories.
\end{abstract}

Keywords: butterflies, moths, abundance, distribution, phenology

\section{Introduction}

Changes in climatic conditions greatly influence the development and range of insects. According to current estimates, the annual average temperature of the Earth increases with $1^{\circ} \mathrm{C}$ by 2025 and the probable rise in temperature by the end of the century is expected to reach $3{ }^{\circ} \mathrm{C}$ (IPCC, 2007). Additionally, forecasts point to higher atmospheric $\mathrm{CO}_{2}$ levels and changing patterns of $\mathrm{UV}$ radiation. The impacts of climate change must be studied from various aspects, such as forestry or agriculture (e.g.: Spencer et al., 2009; Ladányi and Horváth, 2010), human medicine (Kearney et al., 2009; Kiritani, 2006; Takken and Knolsm, 2007), phytogeography (Uniyal and Uniyal, 2009) etc. This vast work requires the interdisciplinal cooperation of research from many different fields (Hilker and Westerhoff, 2007; Strand, 2000), and it must be noted that the effects of human interference, ecosystem-climate control and feedbacks should also be studied (Drégelyi-Kiss et al., 2008).

The order of Lepidoptera is the fourth largest order of insects in Europe with 8470 species living in the area of 35 countries (Karsholt and Razowski, 1996). Due to this species richness, the taxon list of a given area provides an extremely detailed view of the environmental conditions of the site, and this is also true vice versa: butterflies and moths show a sensitive reaction to the change of abiotic factors. Thus, butterflies and 
moths can be considered as good indicator species in monitoring climate change (Ronkay, 2004).

Researchers started to study the potential effects of climate change on Lepidoptera in the early 1990's (Hedden, 1989; Peters, 1990; Watt et al., 1990; Dennis and Shreeve, 1991; Porter et al., 1991; Dennis, 1993; Williams and Liebhold, 1995; Harrington and Woiwod, 1995; Harrington and Stork, 1995). According to Woiwod (1997), climate change has three main impacts on Lepidoptera species:

1. Changes in abundance

2. Changes in range, distribution or area

3. Changes in phenology

It is also necessary to study the potential interactions of these effects. For instance, there is a well documented relation between abundance and distribution, since (temperate) species with the largest number of individuals generally have a large area as well (Lawton, 1995). It is also understood that phenological changes can also affect abundance (via the synchronization of predators and parasitoids with Lepidoptera as prey organisms and also the synchronization of larvae and their host plants (Watt and Woiwod, 1999), or the appearance of one or more extra generations in a year). According to Porter et al. (1991) and Logan et al. (2003) the following possible impacts can be expected in the near future: increasing rate of overwintering, prolonged development stage, changes in the synchronization of host plant and pest, changes in interspecific interactions including modifications in the relation of Lepidoptera and their natural enemies, increasing severity of invasions of migrant pests, changes in the frequency of damages due to gradation and general decrease in biodiversity.

According to Bale et al. (2002) the following problems have to be resolved to clarify the direct impacts of climate change on Lepidoptera:

1. Lepidoptera species already encounter and cope with vast temporal and spatial variability among natural conditions, therefore their reactions to climate change can significantly differ depending on their habitat location (e.g. altitude), feeding regime (e.g. poliphagous or monophagous) and host plant (good or inferior quality) not to mention other biotic interactions. It is hard to decide which effects can be attributed definitely to climate change, and often it is very complicated to separate direct and indirect effects.

2. Even some single factors can often have quite different effects depending on the extent of change and the affected species (e.g. increasing temperature can be harmful for the overwintering of some species by decreasing the snow cover and weakening the synchronization with the host plant, but in a warmer climate the development of some species can accelerate and some species will be able to colonize new areas (Ayres and Lombardero, 2000).

3. The niche width of many species is probably determined, at least in part, by temperature regime. Although we often know which species replace each other along climatic gradients, there is much less information on why one species replaces another.

\section{Changes in abundance: decreasing or increasing number of individuals}

There are many problems to cope with in monitoring abundance changes caused by climate change. First of all, appropriate monitoring requires long-term data series since the individual numbers of Lepidoptera species can show great variability in short term and that can easily lead to misinterpreted short-term trends (Woiwod, 1991). The other 
problem is that even if we had long-term data, the observed changes can not be attributed definitely to climate change because the size of Lepidoptera populations is affected by many factors. These problems can only be overcome by very thorough, long-term study of some species or communities, but such data series are quite rare (Woiwod, 1997).

\section{Decreasing number of individuals}

Since the 1960's the Rothamsted Insect Survey have been collecting light-trap data over 430 points of Great Britain (the number of traps varies from year to year because many light-traps have been operated by volunteers). More than 730 Macrolepidoptera species has been caught since the system started operation, and more than 10 million data have been recorded. In 1995, Pollard et al. predicted a further increasing trend in the area and abundance of the prevalent Lepidoptera species of the British Isles, since the results of the study showed that higher summer temperatures increase the number of Lepidoptera individuals. The results calculated with regression models by Roy et al. (2001) were quite similar: hot summer increased the number of individuals in 28 of the 31 studied Lepidoptera species, especially when the last year was rainy and the current year dry. Forecasts predict increasing abundance of most species, only the Pieris brassicae was seen declining. In contrast with these results, Conrad et al. (2004) conducted a TRIM analysis (Pannekoek and Van Strien, 2001; Van Strien et al, 2001) on a 35-year time series of 338 Macrolepidoptera species and showed that the individual numbers of $54^{\circ} \%$ of the species had decreased. $24^{\circ} \%$ of the species showed a stable population and strong increase in the individual numbers was shown by only 6 species. It was also stated that most species feeding on deciduous trees, shrubs, grass and low growing plants showed decreasing populations, while most lichen-feeders and coniferfeeders were increasing. The number of individuals of most species overwintering in egg stage decreased and fared worse than species overwintering as larvae or pupae, which are also mostly decreasing. Species overwintering as adults, on average, have increased, but the number of species was small and quite variable. The timing of the adult flight period showed an interesting relationship with abundance trends. Only those species which fly through the autumn, winter and spring showed populations which are, on average, increasing. Species which fly at other times of the year showed average (declining) population trends with species that fly only in the autumn or the summer and autumn having the greatest average decrease. In a later study, Conrad et al. (2006) analysed the Rothamsted Insect Survey (RIS) data for 337 species, each of which was represented by more than 500 individuals captured over the 35 -year sampling period (1968-2002). Half of the studied species experienced a 10-year decline of at least $12 \%$, and results suggest that British macro-moths have undergone declines at least as severe as British butterflies: the percentage of moth species declining (66\%) was similar to the proportion of butterflies declining (71\%) and greater than the proportion of birds $(54 \%)$ or plants declining $(28 \%)$.

Conrad et al. (2002) studied the population dynamics of Arctia caja on the British Isles between 1968 and 1999. It was shown that the average number of catches (4.2) rapidly fell after 1983 to 3.0 which is a $28^{\circ} \%$ decline. Many sources reported a declining number of individuals (Rotschild, 2000; Waring, 2000; Conrad et al., 2001) and later the spatial changes were also analysed by the SADIE (Spatial Analysis by Distance Indices) method (Conrad et al., 2006). Three different stages were observed in the spatial distribution: 1969-78 spatial distribution with a strong structure, 1979-90 
almost stochastic distribution, and 1991-99 strong structure again with a powerful decrease in abundance). Conrad et al. (2003) pointed out that besides winter precipitation and spring temperatures the abundance of the species is also affected by the EA-index (East Atlantic teleconnection pattern). No relation was found however between the population dynamics and the NAO (North-Atlantic Oscillation) index significantly determining the winter climate of North Europe. Since the value of EAindex has been considerably growing in the last 5 decades, further decrease in the abundance of Arctia caja can be prognosticated according to the model mentioned above.

Conrad et al. (2003) analysed the Rothamsted Insect Survey (RIS) data between 1968 and 2003 for those species which were represented by at least 500 individuals. It was pointed out that the abundance of 71 species decreased in an extent that these species must be regarded as endangered according to IUCN criteria. Since in the case of these species we do not know about long-range migration, it is quite improbable that these decreasing populations might be "saved" by individuals from the continent.

Roberts et al. (1993) and Gray (1994) observed that the populations of Lymantria dispar can collapse in the United States after winters where the number of warm days was high. The probable reason for this is that warm temperature induces faster rate of metabolism in the individuals and the nutrient reserves needed for overwintering will be exhausted earlier.

\section{Increasing number of individuals}

Salama et al. (2007) studied Macro-moths caught in a Rothamsted trap, operating from 1968 to 2003 as part of the Rothamsted Insect Survey. These data were used to investigate the long-term population trends of moth populations on East Loch Lomondside, Scotland. In total, 367 species of macro moths were recorded during this study. Over the 35 years of this study, an increase was recorded both in the overall number of individuals and moth diversity (Fischer's $\alpha: 19^{\circ} \%$ growth compared to 1968). Four of the most consistently abundant species, collectively constituting $27 \%$ of the average annual catch, were subjected to more detailed analysis. The three species that emerge during the summer months Eulithis populata (the northern spinach), Hydriomena furcata (july highflier) and Idaea biselata (the small fan-footed wave) became more abundant throughout the study period, (although for the latter species not significantly so). For Eulithis populata and Idaea biselata their emergence time became earlier, over the study period and in Eulithis populata and Hydriomena furcata, the flight duration also became longer. In contrast, the species that emerges as an adult during autumn and winter, Epirrita dilutata (the november moth) did not exhibit a significant change in abundance, emergence date or flight duration in this study.

\section{Changes in area (changes in latitude/altitude of dispersion)}

The number of individuals per unit area (density) of Lepidoptera species decreases with higher geographical latitude - Gaston and Williams (1996), Wilf and Labandeira (1999) - and a similar trend can be observed in the case of increasing altitude over sea level. It can be expected that as a result of warming, the majority of Lepidoptera species living in the temperate zone will colonize areas with higher altitude and latitude (Hickling et al., 2006), although this can be limited by the mobility of the species and natural barriers (e.g. host-plant availability, sea, high mountains). 


\section{Horizontal changes in the range of distribution}

Fossil findings show that insects also had to react to climatic changes in the past (Coope, 1970, 1987, 1995; McGavin, 1994; Ashworth, 1997). Wilf and Labandeira (1999) observed increased damage intensity, frequency and diversity on late Paleocene host plant leaves in Southwest Wyoming. These observations prove that damage intensity and diversity of phytophagous insects living on the same latitude increased as a consequence of warming. Change in precipitation patterns can also heavily affect the change in area, though this impact is realized indirectly (via host plants and natural enemies), and it is very difficult to prognosticate. According to Bale et al. (2002), species which currently have wide latitudinal ranges, already encounter considerable temperature variation and are, in a sense, preadapted to cope with temperature change. Loss of habitats or changes in the microclimate of the habitats are severely affecting factors, but these are very difficult to attribute definitely to climate change since the role of human activity seems to be more determining. (E.g. according to Asher (2001), 70 \% of semi-natural habitats have been lost in the British Isles since 1940 due to the intensification of agriculture.) Studying 46 butterfly species in Great Britain, Warren et al. (2001) showed a marked difference between the distribution and abundance of habitat specialist and habitat generalist species: generally area expansion was observed by the generalists and the specialist species showed contraction. Consequently those species whose distribution is primarily limited by climatic conditions (like Polygonia calbum, which appears $220 \mathrm{~km}$ to the North compared to 1970) can be expected to further expand their area. Specialist species with low mobility (like Plebejus argus) will be limited in their colonization of new areas with suitable climate by the great distances between their isolated habitats. Fox et al. (2003) reports a dramatic drop in the number of individuals of low-mobility, specialist species since 1970 (Argynnis adippe, Leptidea sinapis, Boloria euphrosyne, Euphydryas aurinia, Coenonympha tullia, Plebeius argus, Hamearis lucina, Erynnis tages, Boloria selene). Only one habitat specialist species with area expansion has been found (Limenitis camilla). Thomas et al. (2004) studied the distributional changes of 58 Lepidoptera species endemic for Great Britain. Results showed that $71 \%$ of the species suffered area contraction and in the last four decades these species became extinct from $13 \%$ of the $10 \mathrm{~km}^{2}$ quadrates inhabitated in 1970 . Two species become entirely extinct and the extent of area loss significantly exceeded that of plants and birds recorded in the British Isles.

Expansion towards higher latitudes and altitudes are supported by the observations below:

Parmesan (1996) monitored the distribution of Euphydryas editha on the ground of historical data sets at 151 sites in Canada, US and Mexico. Results showed that the species contracted from the southern border of its area and the decrease in individual numbers in low altitudes significantly exceeded that in higher altitudes. This was the first survey which studied the abundance of a Lepidoptera species on the full area of its distribution.

Parmesan et al. (1999) studied the distributional changes of 35 Lepidoptera species in Europe (none of them migratory species). According to their results, $63 \%$ of the species expanded towards North (the Northern border of distribution moved $35-240 \mathrm{~km}$ to the North) and only $3 \%$ of the species showed a southward expansion.

Parmesan and Yohe (2003) monitored 1700 taxa (insects, mammals, fish species, trees, birds and lichens) and observed that their distribution expanded annually $6,1 \mathrm{~km}$ 
to the North or vertically 6,1 $\mathrm{m}$ to higher altitude and events in spring (first singing of birds, arrival of migrant birds, appearance of butterflies, choruses and spawning in amphibians, shooting and flowering of plants) will commence 2.3 days earlier per decade.

Saarinen et al. (2003) reports northward shift of 7 butterfly species based on data between 1991 and 2000 of the National Butterfly Recording Scheme in Finland. Mitikka et al. (2008) constructed a model for the range shift of the map butterfly (Araschnia levana) in Finland for the period of 2000-2004. A significant relationship between annual maximum dispersal distance of the species and late summer temperature was detected, and empirical data showed that between 2000 and 2004 the range of the species moved continuously towards the North, especially in East Finland. Parmesan (2006) also concludes that primarily warm summers induced the northward shift of many North-European Lepidoptera species.

Kuchlein and Donner (1993) reported that Phyllonorycter platani (Gracillariidae) was first caught in 1965 in the Netherlands but since then it became the most common species in the country. Stigter and Frankenhuyzen (1991) reported that since the first catch (1985) of Phyllonorycter leucographella in the Netherlands, the species spread rapidly in the country. According to Vos and Zumkehr (1995), Omphaloscelis lunosa (Noctuidae) was caught only in the Southern part of the Netherlands until 1980, but by 1994 the species became common in the Northern part of the country and even appeared in the relatively cool Frisian Islands (number of annual catches increased from 10 to 260).

Kiritani (2006) cited reports on the northward range expansions of more than 50 butterfly species in Japan, and establishment of permanent populations of 10 butterfly species which had been considered to be migrant species before. Kiritani attributes the increasing abundance of Helicoverpa armigera and Trichoplusia $n i$ to climate change, however his results show that global warming is more favourable for the natural enemies (with the exception of spiders) of the pests, since they are able to develop more generations annually than their preys.

Hill et al. (1999) forecast that Pararge aegeria will colonize all suitable habitats in the next 50 years in the British Isles.

According to one of the theories of theoretical ecology, when the climate of a given area changes, then the areas of the species living in this area and limited by climate in their distribution will also change. This theory was tested by Hellmann et al. (2008) by comparing the northward shift of a small-bodied specialist (Erynnis propertius) and a large-bodied generalist (Papilio zelicaon). Both species showed a positive reaction to warming and both species can expand their areas northwards, but in line with the expectations, the abundance and number of larvae of the large-bodied generalist showed a more powerful growth at the northern edge of distribution than the small-bodied specialist.

According to Thomas et al. (2001) both evolutionary and ecological processes react to climate change, thus playing a role in area shifts. In their study, 4 Lepidoptera species continuously increasing their area in the British Isles during the past 20 years were observed. It was observed that two species (Hesperia comma, Aricia agestis) colonized new types of habitats. Aricia agestis changed its main host plant (among experimental circumstances females participating in the colonization laid two-third of their eggs on Geranium molle which is more prevalent on the newly colonized territories, and only one-third of the eggs was laid on the former main host, Helianthemum chamaecistus). 
Braschler and Hill (2007) pointed out alternative use of host plants by the British Isles populations of the (polyphagous) Polygonia c-album species (Ulmus glabra and Urtica dioica instead of the formerly consumed Humulus lupulus). Nylin et al. (2009) compared the populations of Polygonia c-album in Norway, Sweden, Great-Britain, Belgium and Spain, and found that the host plant preference shifted from Salix caprea to Urtica dioica facilitating rapid development (more generations per year), in regions where the host plant was available.

Species without diapause or overwintering in active form the rate of overwintering individuals will grow as winters become warmer. With the increase in winter average temperatures these species can shift northwards and higher altitudes.

The quiescence of most temperate Lepidoptera species is in winter which is spent in inactive pupa or larva form accompanied by slowing metabolism in order to increase frost tolerance. In most of the species the temperature required to finish winter diapause is lower than the temperature needed for the development, active stage and these reflect the summer and winter temperatures of the given area. Geographical range of some species is limited by the cold tolerance of their winter form, therefore their northern limit of distribution follows the isotherm of the winter minimum temperatures (Uvarov, 1931; Danilevskii, 1965). In case of a warming climate it is expected that the northern distribution of these species will be expanded.

As a consequence of warm winters, at the southern distribution border of some species the temperature will exceed the threshold required for the induction of diapause, so the southern border will shift northwards. For example the rate of survival of individuals in quiescence of Inachis io and Aglais urticae decreases significantly at $10^{\circ} \mathrm{C}$ compared to that at $2^{\circ} \mathrm{C}$ (Pullin and Bale, 1989), and the decrease in the rate is more marked in case of Inachis io. Therefore the southern range of Inachis io follows the isotherm of the $10^{\circ} \mathrm{C}$ mean January temperature, and the southern boundary of distribution of Aglais urticae can be found at a bit lower latitude (Bryant et al., 1997). If winters become warmer, the southern border of distribution will shift northwards, but since Aglais urticae is already present at the northernmost point of Norway (Nordkapp, North Cape, $71^{\circ} 10^{\prime} \mathrm{N}, 24^{\circ} 11^{\prime} \mathrm{E}$ ) and can not move to the North because of the sea, its area will certainly decrease. Hill et al. (2002) monitored 51 Lepidoptera species in the British Isles and observed that 11 out of 46 southerly distributed species have expanded in the northern part of their distributions. For a subset of 35 species, they modelled the role of climate in limiting current European distributions and predicted potential future distributions for the period 2070-2099. Results show that most northerly distributed species will have little opportunity to expand northwards and will disappear from areas in the south, resulting in reduced range sizes. Southerly distributed species will have the potential to shift northwards, resulting in similar or increased range sizes. However, 30 out of 35 study species have failed to track recent climate changes because of lack of suitable habitat.

\section{Vertical changes in the range of distribution}

Hodar and Zamora (2004) monitored the damages of the polyphagous Thaumatopoea pityocampa between 1992-2001 and found that the pest damaged plants at higher and higher altitudes. The vertical distribution of the species is greatly affected by winter temperatures determining the development of larvae. While the upper limit of distribution was around $1500 \mathrm{~m}$ above sea level, the species damaged mainly the Pinus nigra pine species. Following the very warm winters of 1997 and 1998 the moth 
damaged plants at 2000-2100 $\mathrm{m}$ above sea level, where populations of the boreal relict Pinus sylvestris nevadensis can be found. This raises conservation concerns, especially because it is expected that the intensity and frequency of damages and defoliation will both increase due to warmer winters.

Larval development period can become shorter in species where the development/temperature reaction curve grows rapidly, like Saturnia pavonia. This decreases the exposition time to predators/parasitoids (Bernays, 1997). These species are going to expand both in sense of geographical latitude and altitude above sea level. Species however which can be characterized by long larval period, slowly growing development/temperature curve, narrow ranged and low optimum temperatures (e.g. Lasiocampa quercus callunae), will face the challenge that habitats in the South and at low altitudes become too hot and these species are forced to shift their ranges to the North and higher altitudes (Bale et al., 2002). A similar reaction can be expected by species with two or more years of life cycle, where slow development decreases the opportunity of quick adaptation.

According to Butterfield and Coulson (1997), those species can be considered vulnerable which live among heavily limited climatic conditions, especially mountainous and cold-adapted species. Wilson et al. (2005) studied the Lepidoptera fauna of central Spain. It was observed that the lower elevational limits of 16 butterfly species had risen on average by $212 \mathrm{~m}$ between 1967 and 2004, accompanying an increase of $1.31 \mathrm{C}$ in the mean annual temperature (equivalent to an approximate $225 \mathrm{~m}$ uphill shift in isotherms). The vertical changes in these Lepidoptera species mean the loss of approximately one-third of suitable habitats, and this is expected to increase to $50-80 \%$ during the $21^{\text {st }}$ century.

Vertical changes had also been observed in the tropical areas: Chen et al. (2009) studied the Geometrid population of Mount Kinabalu in Borneo and reported that the area of 102 montainous species shifted upwards by 67 metres in average in the last 42 years.

\section{Models, forecasting changes in area using climate scenarios}

"Climate envelope" models are used to forecast future distribution of species. "Climate envelope" is the set of environmental and climatic variables. Populations of species are able to live, feed and propagate between the upper and lower limits of these variables. This principle is applied by many computer programs, for instance CLIMEX, HABITAT, BIOCLIM and DOMAIN. Other researchers use linear models and GIStechniques to forecast area shifts. These models are frequently used to prognosticate future distributions of artificially colonized, introduced species, e.g. Chiasmia inconspicua and C. assimilis (Palmer et al., 2007) and Euclasta whalleyi (Mo et al., 2000) in Australia, or to forecast the global distribution of species, like in the case of Cactoblastis cactorum (Legaspi and Legaspi, 2010). Petrányi et al. (2007) used the most widely accepted scenarios (IPCC, 1990, 1995, 2001, 2007; Murphy, 1995) of global general circulation models, Hungarian meteorological data of OMSZ (Hungarian Meteorological Service) and the CRU grid database of IPCC to create a forecast of the future changes of the Hungarian Lepidoptera fauna with a method applying geographical analogies. Results showed that moving southward on the Balkan peninsula, the share of members of Hungarian fauna gradually decreased and the proportion of species leaving or becoming extinct in Hungary and also the proportion of 
species potentially migrating to Hungary because of changing climate increased. Data obtained for the whole Lepidoptera order were compared with similar data gained for Macrolepidoptera and Microlepidoptera. It was observed that Macrolepidoptera data were significantly higher and Microlepidoptera data were significantly lower than those obtained for the entire order. Supposedly, this can be attributed to better flying and migratory characteristics of Macrolepidoptera. By studying individual species of Macrolepidoptera families it was found that Sphingidae species (with the best flying abilities) had the least endemic species in Hungary, while Geometridae species showed a relatively high proportion of endemic species, therefore these species are appropriate indicators of climate change in Hungary. As a summary, it was concluded that in case of realization of the studied scenarios, their effect would not impact 55-81\% of the Hungarian Lepidoptera fauna. Loss of the current fauna in species would attain 19-45 \% at most, and these are species living on the northern limit of their distribution. The appearance of new species can be expected at most in a proportion of 19-31\% of the current fauna, and the area of these species is mainly of South-eastern character.

Some ecologists heavily criticize climatic mapping models and also call the attention that the area shift of a given species is the result of the complicated effects of many different factors; and currently we don't have appropriate knowledge on interspecific relations. What's more in many cases we have only scarce understanding on the most important physiological parameters of a single species (Davis et al., 1998; Lawton, 1998; Hodkinson, 1999; Baker et al., 2000). Araujo and Luoto (2007) stated by monitoring the European distribution of Parnassius mnemosyne with the "climate envelope" method, that biotic interactions heavily affect the predictive power and reliability of such models. Pearson and Dawson (2003) determined three general nonclimatic factors fundamentally affecting the distribution of a given species:

1. biotic interaction like competition and predation

2. fast local evolution inducing area shift without environmental changes

3. limiting effect of barriers.

However, even the hardest critics of climate mapping models recognize that these methods can be applied with great benefits as a "first approach" or "null models".

Thomas et al. (2004) applied a model created on the basis of the „climate envelope" method on $20 \%$ of the Earth's terrestrial area and used three different scenarios (slight, medium and drastic change) to prognosticate the number of species (mammals, birds, Lepidoptera, reptiles, frogs and plants) becoming extinct as a consequence of climate change. Results show that by $2050,18-35 \%$ of the studied taxa can disappear depending on the pace of change.

Zalucki and Furlong (2005) made forecasts with the CLIMEX model on the expansion of Helicoverpa punctigera and H. armigera in Australia. Using Australian climate data as a starting point, it was also determined where future expansion of $H$. armigera can be expected around the globe.

Beaumont and Hughes (2002) simulated the future area of 24 Australian Lepidoptera species by using BIOCLIM climate models. In case of a very conservative climate scenario $\left(0.8-1^{\circ} \mathrm{C}\right.$ rise in temperature by 2050$), 88 \%$ of species with relatively wide temperature optimum showed area contraction, and in $54 \%$ of the species this contraction exceeded $20 \%$ of their current area. When applying an extreme scenario $\left(2.1-3.9^{\circ} \mathrm{C}\right.$ rise in temperature by 2050$)$, it was found that $92 \%$ of he species showed contraction in their distribution, and $83 \%$ of the species the extent of contraction exceeded $50 \%$ of their current area. 
Gutierrez et al. (2006) applied four different climate scenarios to forecast the future distribution of Pectinophora gossypiella, a pest damaging cotton plantations in California and Arizona. The scenarios of the GIS-based simulation reflected 1, 1.5, 2, and $2.5^{\circ} \mathrm{C}$ rise in daily maximum and minimum temperatures, and models also contained further variables representing values of solar radiation, precipitation, nitrogen content of soil, relative humidity and wind speed. Practically no impact was found as a consequence of 0.5 and $1^{\circ} \mathrm{C}$ rise in average temperature, but when the rise in average temperature reached $1.5^{\circ} \mathrm{C}$ the size of population surviving the winter grew significantly and the area of feeding (damaging) also expanded. This species is not considered yet as a serious pest in the South-Eastern states of the US. Venette and Hutchinson (1999) studied in a CLIMEX simulation that what areas can be expected to be colonized by the pest. Results show that the area expansion and serious damages of the species are inhibited by high amounts of precipitation and cold summer and winter temperatures. The model shows that there is $80 \%$ chance that by rising temperatures, the species can appear and can cause severe damages in some parts of Arkansas, Louisiana, Mississippi, Alabama, Florida and Georgia.

The model by Fleming and Candau (1998) forecasts increasing severity of defoliation by Choristoneura fumiferana (Tortricidae) in Canadian pine forests due to decreasing number of late spring frosty days. The model by Hassell et al. (1993) suggests that if the tortricid larvae serving as hosts of parasitoids hatch earlier and earlier, they can avoid the appearance of adult parasitoid forms. As a consequence of the "refuge in time" phenomenon, it is possible that larvae can entirely avoid the threat of parasitoids. Based on the CGCM3-B1 climate scenario, Gray (2008) forecasts that between 2081 and 2100 (atmospheric carbon-dioxide level reaches $550 \mathrm{ppm}$ ) the defoliation damage by Choristoneura fumiferana will increase by $15 \%$ in EastCanadian pine forests, the length of gradation periods will increase due to drier and warmer climate and the damages caused by the species will shift northwards.

Some researchers use life-cycle based classic eco-physiological models to study the impacts of climate change (Kingsolver, 1989; Logan et al., 1976; 2003). These models consider the metabolism of the larvae, thermoregulation and effects of temperature exerted on the insects via host plants. Yamamura and Kiritani (1998) used heat unit models for rapid estimation of potential changes in number of generations per year. Morimoto et al. (1998) prognosticated the future expansion of three damaging Lepidoptera species (Plutella xylostella, Chilo suppressalis, Ephestis kühniella) and a Coleoptera (Tenebrionidae) species (Tribolium confusum) by a model using heat units, photoperiodic conditions, maximum and minimum temperatures. Results showed that in case of a $2^{\circ} \mathrm{C}$ increase in annual average temperature, $P$. xylostella could develop 2 extra generations per year, and the distribution of $C$. suppressalis can spread northwards by $300 \mathrm{~km}$.

\section{Phenology}

\section{Earlier flight}

According to Woiwod (1997), many factors can influence the beginning of the flight period, but temperature and precipitation immediately preceding the flight have the greatest effects. Since temperature (heat units) is of fundamental importance, the start of flight is one of the climate change related phenomena which can be studied easiest. 
Studying the effects of climate change does not solely include monitoring of the beginning of the flight, but also the length of the flight period of adults and the time elapsed between generations and number of generations per year. Brakefield (1987) studied the flight of Maniola jurtina and Pyronia tithonus and showed that the extent of flight asynchronities can be different in species depending on habitat preference. Wing spotting and body size (smaller) of Maniola jurtina populations flying later in the year were significantly different from those individuals flying earlier (Brakefield, 1987).

Forister and Shapiro (2003) studied the first appearance of flying adults of 23 Lepidoptera species in California on a 31-year time series. It was observed that the first observation dates of individuals of species flying significantly earlier in this area of Mediterranean climate became earlier by 42 days in general.

Earlier flight of Macrolepidoptera was observed by Stefanescu et al. (2003) when analyzing trap data from 1988-2002 in Spain. The average date of the first flight of 8 species among the 19 species caught in large numbers advanced significantly.

Kearney et al. (2010) studied the appearance of Heteronympha merope in Southeast Australia, near to Melbourne by using data from 1941-2005. In the last 65 years the mean date of flight advanced by 1.5 days per decade - the average increase in temperature in this period had been $0.16^{\circ} \mathrm{C}$ per decade.

Kuchlein and Ellis (1997) monitored 104 Microlepidoptera species in the Netherlands which had been caught at least 30 individuals per year. It was observed that the first date of appearance of these species advanced by 11.6 days between 1975 and 1994. This was attributed primarily to warmer springs, the influence of warmer summers was found less determining.

Since it had been observed in Great Britain that mites usually appeared earlier on agricultural fields than in the 1960's, Woiwod (1997) studied at six sites whether this phenomenon could be observed at Lepidoptera species. For the sake of simplicity, only univoltine species were studied only at those sites where at least 20 individuals per year had been caught, and 5, 25, 50, 75 and 95 percentile of the appearances were studied. Results showed that Orthosia gothica flew almost a month earlier than in 1976 with all percentiles being significant. As a result of expanded monitoring, Woiwod (1997) found significant differences at 93 species, 88 showing earlier and 5 later mean dates of appearance. These results were quite similar to those found at mites by Zhou et al. (1996). It was concluded that during the next 20-30 years the first appearance dates of most mite and Lepidoptera species will advance depending on the pace of warming. Roy and Sparks (2000) prognosticated that $1{ }^{\circ} \mathrm{C}$ rise in the annual average temperature of the British Isles moves the start and peak of flight period earlier by generally 2-10 days.

\section{Later flight}

Woiwod (1997) observed that the species Xestia xanthographa caught at Cockayne Hatley light-trap behaved in a very interesting way, since this has been the only species at which the appearance of the flying adults slid to a later date during the past 20 years. The appearance of this species is relatively late, so it was supposed that the appearance can move to an even later date as a response of further warming. A similar phenomenon was described by Buse and Good (1996) during experimental conditions by Operophtera brumata. 


\section{Appearance of extra generations}

Future warming will affect species with different generations per year in a different way and extent. Higher temperatures (ceteris paribus) can result in faster development and consequently the appearance of extra generations in multivoltine species, like Pieris brassicae (Pollard and Yates, 1993). The area of most of these species might expand to higher latitudes and altitudes (Pollard et al., 1995; Hill et al., 1999; Parmesan et al., 1999).

Altermatt (2009) studied 355 bi- or multivoltine Lepidoptera species in Central Europe and observed augmented frequency of second and subsequent generations relative to the first generation in a warm period since 1980, and 44 species even increased the number of generations after 1980 .

In case of $2^{\circ} \mathrm{C}$ increase in mean temperature, Morimoto et al. (1998) forecast the appearance of two new generations per year by Plutella xylostella in Japan.

Tobin et al. (2008) studied the phenology of the multivoltine Paralobesia viteana and found that the importance of warmer winters and springs is especially high, since the species begins diapause 2-3 weeks after the summer equinox (therefore the increase of heat units after this date has a limited effect on voltinism). An increase of above $2{ }^{\circ} \mathrm{C}$ in mean temperatures however, can significantly bring forward the egg-laying of the second generation, so the probability of appearance of a third generation grows.

Effects of influencing factors, climatic components and interspecific relations (temperature, atmospheric $\mathrm{CO}_{2}$ content, UVB radiation, wind, precipitation, predators and parasitoids)

Undoubtedly, temperature can be studied and measured easiest among all the environmental conditions, this is why the decisive majority of the already published studies deal with this factor and its effects. Climate change results however not only in the change of temperature conditions, but affects the metabolism, phenology and distribution of Lepidoptera in many ways.

\section{Changes in temperature}

Change of temperature can modify the life of Lepidoptera in many ways: the length of the life-cycle (development rate), voltinism, density and size of population, the genetic structure of the population, the extent of host plant exploitation, colonization of new areas, geographical distribution (presence-absence) can be altered. In most of the species, the limiting facto is the lack of the summer warmth (heat units), and not the appearance of the lethal heat stress. Bale et al. (2002) states however, that the effects of temperature change are frequently contradictory. Higher temperatures can help to accelerate the development of individuals and increase the survival rate but these 4 can accompanied by lower adult body mass and lower fertility. There are some examples that the development rate of some species showed temperature-independence during examinations conducted in transects including areas from different altitudes, but laboratory trials detected temperature-dependence in these species, e.g.: (Butterfiled, 1976; Coulson et al., 1976; Fielding and Tatchell, 1995). The reason for this is that insects are able to actively manipulate their thermal micro-environment (May, 1979; Heinrich, 1977; Porter, 1982; Bryant et al., 2000). 


\section{Change in atmospheric $\mathrm{CO}_{2}$-content: Impact of changing atmospheric $\mathrm{CO}_{2}$-content on Lepidoptera through host plants}

The effect of increasing atmospheric $\mathrm{CO}_{2}$-levels to Lepidoptera can be quite various (Bezemer and Jones, 1998; Whittaker, 1999). According to Coviella and Trumble (1999), increasing atmospheric $\mathrm{CO}_{2}$-levels can have four main consequences to insect populations:

1. Local disappearance of some species.

2. Changes in the grading of some insect species (endangered, pest).

3. The area of some species will be changed, limited to the areas where exploitable host plants can be found.

4. Population dynamics of some species can be changed, and this will affect the interactions with other insects and plant species.

High $\mathrm{CO}_{2}$ levels are unfavourable for the larvae, primarily because of the altered physiological attributes of the host plant. Almost all studies agree that the survival of the larvae decreases due to the unfavourable content of the food (lower water and nitrogen content, increased $\mathrm{C}: \mathrm{N}$ ratio, higher phenolic compound and tannin content, and their development period becomes longer. In these cases compensatory feeding is quite characteristic: larvae consume more (up to $25 \%$ more) from the inferior food. Contradictory conclusions have been drawn from the studies: according to forestry trials, increasing atmospheric $\mathrm{CO}_{2}$ content (ceteris paribus) can lead to decreased level of defoliation (Knepp et al., 2005), while others state that due to compensation feeding, the intensity of damages is expected to grow (Lincoln et al., 1984).

Plants where eggs are to be laid on can be more hardly found by females of some Lepidoptera species at high atmospheric $\mathrm{CO}_{2}$ levels.

Results of studies conducted on Lepidoptera and Orthoptera larvae at high atmospheric $\mathrm{CO}_{2}$ levels (Lincoln et al., 1984, 1986, 1993; Lincoln and Couvet, 1989) showed decreasing populations, however the extent of decrease was not significant in every case.

Agrell et al. (2003) studied the effect of normal $(387 \pm 8 \mu 1 / 1)$ and elevated $(696 \pm 2$ $\mu 1 / 1)$ atmospheric $\mathrm{CO}_{2}$ content on Orgyia leucostigma larvae on three tree species among different light conditions. Higher $\mathrm{CO}_{2}$-concentration had a massive impact on the chemical composition of the foliage of the tree species: reduced water and nitrogen content with higher starch, phenolic glycoside (salicortine and tremulacine) and tannin content. The survival rate of larvae decreased by $62 \%$, development time increased and larval mass significantly decreased.

Goverde and Erhardt (2003) studied the development of Coenonympha pamphilus (Satyridae) larvae at elevated $\mathrm{CO}_{2}$ concentration on four host plants. It was observed that due to the changes in the nutrient content of the plants, the development of larvae took 2 days longer in average, and plants gave different reactions on the change in $\mathrm{CO}_{2}-$ content which can affect host plant selection in the future.

Johns and Hughes (2002) studied the development of Dialectica scalariella (Gracillariidae) introduced to Australia for the control of the weed Echium plantagineum (Boraginaceae) on host plants grown at elevated $\mathrm{CO}_{2}$ level. Results showed that the mortality of the larvae increased, the body-mass of the adults decreased and their development required longer periods. Lincoln et al. (1984) studied the development of Pseudoplusia includens (Noctuidae) at three different atmospheric level of $\mathrm{CO}_{2}$ on soy host plants. Due to decreasing nitrogen content of the leaves, 
consumption of the larvae increased at higher $\mathrm{CO}_{2}$ levels, therefore authors concluded that increasing damages of herbivore insects can be expected at elevated $\mathrm{CO}_{2}$ levels.

Slower development and higher mortality of Junonia coenia (Nymphalidae) larvae fed by Plantago lanceolata host plants grown in atmosphere with elevated atmospheric $\mathrm{CO}_{2}$ content (350 and 700 ppm CO $\mathrm{CO}_{2}$ ) have been observed by Fajer et al. (1989). Authors concluded that this was caused by lower water and nitrogen content and not by the change in the concentrations of defensive metabolites (glucosides). However, in a following series of studies, slower development of larvae was not observed (Fajer et al., 1991).

According to the results of Dury et al. (1998), larval development of Operophtera brumata was detrimentally affected by increased phenolic content and decreased nitrogen content of oak leaves due to higher $\mathrm{CO}_{2}$ levels. Those Lepidoptera species that are not able to feed longer than normal (Slansky, 1989) - in order to compensate lower nitrogen content - become vulnerable for their natural enemies (Hochuli, 1996). According to Woodward (1992) the effect of elevated $\mathrm{CO}_{2}$ on the quality of foliage can vary between plant species, and Lloyd and Farquhar (1996) state that the nutrient content of the soil also has a great impact in this respect. The reaction of different Lepidoptera species to elevated $\mathrm{CO}_{2}$ levels can also be different, e.g. the performance of Lymantria dispar improved on Quercus rubra while Malacosoma disstria did not show any changes. At elevated $\mathrm{CO}_{2}$ levels the development of Lymantria was unchanged while that of Malacosoma disstria decreased on Acer saccharum (Lindroth et al., 1993). This is supported by the observation of Traw et al. (1996), that the productivity of Lymantria dispar in an elevated $\mathrm{CO}_{2}$ atmosphere depends heavily on the host plant. Buse et al. (1998) also states that the effect of $\mathrm{CO}_{2}$ on larval development is not unanimous.

Stiling and Cornelissen (2007) studied the development of 6 leaf-miner species in a 9 -year series of studies at elevated $\mathrm{CO}_{2}$ levels on 3 different host plants. Results showed that high $\mathrm{CO}_{2}$-content decreased abundance of species by $21.6 \%$, increased relative food utilization by $16.5 \%$ and development time by $3.87 \%$ and total consumption by $9.2 \%$. The feed conversion of individuals and pupal mass decreased significantly ($19.9 \%$ and $-5,03 \%$ respectively).

Stange (1997) observed that the $\mathrm{CO}_{2}$-emission of Opuntia stricta host plants play an important role in the egg-laying of Cactoblastis cactorum females. Released $\mathrm{CO}_{2}$ is captured by special receptors of the females and eggs are laid on the healthiest plants. At elevated $\mathrm{CO}_{2}$ levels, females tend to find host plants more slowly and number of laid eggs also showed a significant decline.

\section{Changes in the intensity of $U V-B$ radiation}

According to the results of the (relatively small number of) available studies, increasing UV-B radiation is very unfavourable for Lepidoptera species. This is because the defensive mechanisms of host plants are unfavourable for the Lepidoptera, and some data describing tritrophic interactions are also state that parasitoids prefer the weakest larvae.

Hatcher and Paul (1994) studied the effect of elevated UV-B radiation on Autographa gamma larvae feeding on pea. According to their results the phenolic compound and nitrogen content of plants increased significantly, but this affected the feeding of the larvae only in a small extent. Due to increased nitrogen content, larvae utilized the consumed plant parts more effectively, however their total consumption 
decreased slightly. McCloud and Berenbaum (1994) observed definitely unfavourable effects when studying the survival of Trichoplusia $n i$ larvae on Citrus jambhiri leaves exposed to UV-B radiation, because the plant metabolized toxic fumarocumarines as a response to radiation.

Caputo et al. (2006) observed no significant reactions of Plutella xylostella larvae on Arabidopsis thaliana host plant when exposed to UV-B radiation, female adults however laid significantly less eggs in case of stronger radiation. According to the results of the studies conducted by Foggo et al. (2007), scars done by Plutella xylostella larvae on irradiated plant were smaller and more shallow, though the number of scars was higher (but not significantly). When females could choose between irradiated and untreated plants, most of them preferred the untreated plants for egg laying. It was also observed that females of the parasitoid Cotesia plutellae species preferred those larvae that were feeding on irradiated plants.

\section{Changes in precipitation, impacts of drought}

Drought periods are expected to become more frequent which is going to increase the intensity of damages by herbivore insects due to various reasons. First, according to Mattson and Haack (1987) the temperature of plants exposed to drought stress is $2-4^{\circ} \mathrm{C}$ higher than those with appropriate water balance (closure of stoma inhibits transpiration cooling), therefore these plants provide a favourable microhabitat for pests, this way facilitating their fecundity (Sanders et al., 1978) and accelerating their development (Lysyk, 1989). Second, the concentration of metabolites facilitating the fecundity of female Lepidoptera (carbohydrates, protein-hydrolizates) in the host plant with water deficit stress increases (Martinat, 1987). This is the reason why the frequency of total defoliation and a northward shift in the geographical distribution of damages by defoliators was prognosticated in North America by Williams and Liebhold (1995), Hanson and Weltzin (2000), Volney and Fleming (2000) and Logan et al. (2003), though in some Lepidoptera species (e.g. Aglais urticae) drought decreased fertility (Pollard et al., 1997).

\section{Changes in the activities of predators and parasitoids}

The most important factor determining the efficacy of natural enemies are: weakening of prey-predator (parasitoid) synchronization i.e. the ,refuge in time” effect (Fleming and Candau, 1998), variability of the climate, extreme weather phenomena and conditions (Stireman et al., 2005), changes in the foliage structure of host plants (Chen and Welter, 2007), proximity of host plants of alternative prey species and the presence or absence of the regional source population (Bell et al., 2006).

Fleming and Volney (1995) observed that the tortricid Choristoneura fumiferana propagates earlier and earlier due to increasing temperature in Canada, and this way the species might avoid the parasitoids in time.

Hance et al. (2007) studied the effects of extreme temperatures on parasitoids and reported that due to the difference in thermal preferences the synchronization of hostparasitoid relation can weaken both in space and time, which can lead to gradations. Thomson et al. (2010) monitored the distribution of natural enemies of the polyphagous tortricid Epiphyas postvittana in Australia and New Zealand and called the attention of the plant protection experts to the importance of alternative host plants of parasitoids. 
Visser and Holleman (2001) described and Walther et al. (2002) also mentioned that due to warmer springs, the budburst of oaks and the synchronization of Operophtera brumata had weakened, and as a consequence the moth is less available for its predator (Parus major). This causes severe disturbance in the propagation of the predator (Visser et al., 1998).

\section{Changes in species numbers, biodiversity and migrations}

\section{Observed changes in some communities}

Panigaj and Panigaj (2008) monitored the Lepidoptera population of the Temnosmrecinská valley (Slovakia, High Tatra) at seven sites and compared the catch data with those 55 years before. 15 members of the earlier species list had disappeared, but 6 new species have been caught. The main reasons for this were the changes in abiotic factors and plant communities. Number of species which were caught at more than one site simultaneously decreased significantly, and the number of species which were caught at only one sight has grown. Kulfan and Zach (2006) also reported about the change of abundance and structure of local Lepidoptera communities in Skalnatá valley (High Tatra, Slovakia), which can be traced back to the change of climatic conditions.

Franzen and Johannesson (2007) monitored both nocturnal and diurnal Macrolepidoptera communities on approx. $100 \mathrm{~km}^{2}$ in the Kullaberg Nature Reserve, Sweden. The findings were compared with a species list from 1950. According to the results, out of 597 species, 159 (22\%) formerly on the list disappeared and 22 new species appeared. The extent of decrease in species numbers was higher in case of diurnal butterflies and moths than in nocturnal and other Macrolepidoptera species. Individual numbers of disappeared species showed a strong decline in Finland as well and individuals of species observed in Kullaberg were also caught in Finland. In case of species not showing any change in abundance, Finnish trap data remained constant. $70 \%$ of habitat specialist species disappeared and not just from the nature reserve but also the Finnish traps were not able to catch them, so it was concluded that this change of the latest 50 years affected a large area.

Bolotov (2004) reported that abundance and dominance characteristics of the taiga Lepidoptera fauna of the Western Russian Plains has changed significantly due to warming that started in the early 1990s. Species with formerly southern distribution appeared in the area (Gonopterix rhamni, Euphydryas maturna, Melitataea athalia, Limenitis populi, Argynnis paphia, Argynnis aglaja), and some migrant species also appeared who were not able to adapt to the conditions in an extent to settle down, but were regularly observed in the area (Vanessa atalanta, Vanessa cardui, Inachis io, Colias hyale). Following the warm years of 1977-1978 and 1983, settling of southern species was observed on the southern part of the Jamal-peninsula by Bogacheva and Olschwang (1978), Olschwang (1992) and Bogacheva (1986), and also on the northwestern part of the Kola-peninsula by Isakov and Gromov (1997), but in the latter case, the settled population had been decimated by the first hard winter.

The GIS-based model processing data on 292 Lepidoptera species by Kerr (2001) shows the importance of habitat heterogeneity. Results showed that different types of plant cover present in the same quadrate heavily affected the species richness of the given area. 


\section{Appearance of invasive species}

Invasive or introduced species can severely affect the native biodiversity of the area. $40 \%$ of North America's main insect pests are introduced (Niemela and Mattson, 1996), this ratio in Great-Britain is around $30 \%$, and what's more, $62 \%$ of the 29 main defoliators damaging forests are not indigenous (Pimentel, 2002). The success of invasion is determined by various factors which can be modified by climate change in different directions, therefore it is quite complicated to forecast the final impact (Ward and Masters, 2007)

By studying some species, predisposing attributes which facilitate the species to become invasive can be defined. The most important attributes are as follows:

1. A wide range of diet (generalist/specialist)

2. Phenological plasticity (voltinism)

3. Life-cycle strategy (overwintering, frost tolerance)

4. Mobility and fast reproduction ability, introduction pressure

\section{Width of diet range (generalist/specialist species, mono-/polyphagy)}

Invasion success is often linked with the width of diet range (Ehrlich, 1986; Simberloff, 1989). Generalist species have greater chance to find some kind of suitable food plant on a new area than specialist species feeding on only one or just a few plant species. However, taxonomic generalism can mean nutrient specialism in many cases (McNeill and Southwood, 1978; Lawton and McNeill, 1979; Bernays and Minkenberg, 1997), and it is also possible that the reason why a species is a generalist is that it has such a mixed nutrient requirement which can only be satisfied by consuming various plant species (Bernays et al., 1994). A specialist species often consumes only one plant species or just plant species belonging to the same order or family, but it is also possible that a specialist species become able to cope with the changing nutrient concentration of the plant (McNeill and Southwood, 1978). It is also possible that though generalists have a broader food-plant range, they can not cope with the increasing phenolic compound and decreasing nitrogen concentration of the plants which is expected due to increasing $\mathrm{CO}_{2}$-levels (Bezemer and Jones, 1998). This is especially true in case of species belonging to such a guild the members of which do not conduct compensation feeding (Hamilton et al., 2004). And finally, it is also possible that a given species changes food plant in a new area, or increases its diet range (Pearson and Callaway, 2003).

\section{Phenological plasticity}

A tight synchrony can be observed between herbivore insects and their food plants (those periods when the food plant is available). A good example for this is the Lymantria dispar (Hunter and Elkington, 2000), feeding on Quercus rubra and Quercus velutina species. If there is no alternative food plant and larvae hatch before budburst, they won't be able to find food and if they hatch well after budburst, the quality of the food will not be appropriate, so the fecundity of the species decreases. Phenological events of the spring (budburst, flowering) are becoming earlier and earlier (Sparks et al., 1997, 2000; Fitter and Fitter, 2002), which can severely affect the insect feeding on a given plant species. 
Due to earlier springs, the length of the active period increases, which can be quite favourable for multivoltine species. A given food plant can become available for more Lepidoptera species than before. Therefore invasive species are expected mostly to require less tight synchronization with the given host plant (including multivoltine species).

\section{Life-cycle strategy, overwintering, frost tolerance}

Detailed knowledge on the biological processes of overwintering and frost tolerance can provide a good indication on whether the survival of a species is possible or not in the new area (Bale and Walters, 2001). However, we do not possess these information in case of many species. Overwintering strategies of individual species are quite well known on the other hand. Most temperate species have some kind of winter diapause (Leather et al, 1993), which is generally obligate in univoltine and facultative in multivoltine species, where diapause is induced by some abiotic or biotic triggers. According to Bale et al. (2002) the area of those species will be expanded which are multivoltine, developing quickly, have no diapause, and those species which do not require low temperatures to induce diapause. Fast individual development can also be a decisive factor of the success of invasion (Lawton and Brown, 1986; Crawley, 1987).

\section{Mobility and fast reproduction ability, introduction pressure}

Introduction pressure is a function of the number and reproduction rate of propagules introduced to the new area, and these factors are determined by the mobility of the species and the size of the new area and the distance from the source habitat. (Lockwood et al., 2005; Memmott et al., 2005). Changes in climate can provide better conditions for those species expanding in their flying form, since they can reach new areas in times when conditions are suitable for colonization, e.g. developing a new generation.

The success of colonization is heavily affected by the reactions of local communities to newly arriving populations (nutrients, niches). Various theories tried to explain the success of invasion and the extent of the newly establishing diversity, e.g. the theory of fluctuating resources (Davis et al., 2000), and the intermediate disturbance hypothesis (Grime, 1973; Horn, 1975; Connell, 1987; Roxburgh et al., 2004). Human impacts must not be disregarded and these can be either unfavourable (destruction of habitats etc.) or favourable (introduction of species, establishment of protected environment for example with glasshouses or production of new host plants).

\section{Summary and outlook}

As a consequence of climate change, changing conditions exert various effects on Lepidoptera communities. Results of faunistical studies decisively show decreasing number of individuals, however the role of human impacts must be huge in this respects. A number of studies showed the horizontal and vertical expansion of butterflies and moths. Temperate Lepidoptera species show a general trend of expanding towards higher latitude and altitude, which is also supported by the forecasts of the applied models. Higher mean temperatures induce earlier flight of adults, appearance of new generations and due to area changes, food plant changes also can be 
observed in case of some species. One of the reasons for this is the weakened synchronization with the food plant. Increasing $\mathrm{CO}_{2}$ levels are usually unfavourably affecting larvae, causing lower body mass and worse feed conversion. Intensification of UV-B radiation is also detrimental for the development of the larvae due to the enhanced defensive mechanisms and tritrophic interspecific interactions. Drought reduces the reproduction success of many Lepidoptera species, though defensive mechanisms of plants are expected to weaken, therefore the intensity of damages by some species is prognosticated to grow.

Predicting and monitoring the impacts of climate change have many pitfalls and challenges, which can fundamentally affect the results, e.g. human activity causing the destruction of habitats etc. According to Bale et al. (2002) future research must consider the following aspects:

1. By predicting the direct impact is of climate change on Lepidoptera and other insect species, the phenotipical and genotipical flexibility of individual species must also be considered.

2. Much greater attention has to be paid to the interactions of climatic factors. For example the direct effect of temperature can be modified by changes in precipitation, and this can affect relative humidity which greatly determines physiological functions (e.g. reproduction, fertility). Besides, direct impacts of climate change on the development of Lepidoptera and other insects must be interpreted in a broader context, especially in regard of natural enemies and host plants.

3. We have only little knowledge on the long-term population level responses and reactions of Lepidoptera and other insects to global environmental changes.

4. Scientific studies should be extended to other biological systems (e.g. terrestrial and sweetwater systems). The majority of currently available research results deal with terrestrial insects.

These ideas support the need for cooperation of researchers from various fields of science in order to clarify the individual effects and their complex resultant impacts.

Acknowledgements. This work was supported by the MTA TKI Adaptation to Climate Change Research Group, Research Assistant Scholarship Grant of CUB, Bolyai János Research Scholarship of MTA Doctoral Council, „ALÖKI” Alkalmazott Ökológiai Kutató- és Igazságügyi Szakértői Intézet Kft., and the TÁMOP 4.2.1/B-09/1/KMR/-2010-0005 project.

\section{REFERENCES}

[1] Agrell, J., McDonald, E.P., Lindroth, R.L. (2003): Effects of $\mathrm{CO}_{2}$ and light on tree phytochemistry and insect performance. - Oikos 88(2): 259-272.

[2] Altermatt, F. (2009): Climatic warming increases voltinism in European butterflies and moths. - Proc. R. Soc. B 2010 277: 1281-1287.

[3] Araújo, M.B., Luoto, M. (2007): The importance of biotic interactions for modelling species distributions under climate change. - Global Ecology and Biogeography 16: 743753.

[4] Asher, J. et al. (2001): The Millennium Atlas of Butterflies in Britain and Ireland. Oxford Univ. Press. 
[5] Ashworth, A.C. (1997): The response of beetles to quaternary climate change. - In: Past and Future Rapid Environmental Change (eds: Huntley, B., Cramer, W., Morgan, A.V., Prentice, H.C., Allen, J.R.M.), pp. 401-412. Springer, Berlin.

[6] Ayres, M.P., Lombardero, M.J. (2000): Assessing the consequences of global change for forest disturbance from herbivores and pathogens. - The Science of The Total Environment 262(3): 263-286.

[7] Baker, R.H., Sansford, A.C.E., Jarvis, C.H., Cannon, R.J.C., MacLeod, A., Walters, K.F.A. (2000): The role of climatic mapping in predicting the potential geographical distribution of non-indigenous pests under current and future climates. - Agriculture, Ecosystems \& Environment 82: 57-71.

[8] Bale, J.S., Masters, G.J., Hodkinson, I.D., Wmack, C.A., Bezemer, T.M., Brown, V.K., Butterfield, J., Buse, A., Coulson, J.C., Farrar, J., Good, J.E.G., Harrington, R., Hartley, S., Jones, T.H., Lindroth, R.L., Press, M.C., Symrnioudis, I., Watt, A.D., Whittaker, J.B. (2002): Herbivory in global climate change research: direct effects of rising temperature on insect herbivores. - Global Change Biology 8: 1-16.

[9] Bale, J.S., Walters, K.F.A. (2001): Overwintering biology as a guide to the establishment potential of non-native arthropods in the UK. - In: Environment and Animal Development: Genes, Life Histories and Plasticity (eds Atkinson D, Thorndyke M), pp. 343-354. BIOS Scientific Publishers Ltd, Oxford.

[10] Beaumont, L.J., Hughes, L. (2002): Potential changes in the distributions of latitudinally restricted Australian butterfly species in response to climate change. - Global Change Biology 8(10): 954-971.

[11] Bell, V.A., Brightwell, R.J., Lester, P.J. (2006): Increasing vineyard floral resources may not enhance localised biological control of the leafroller Epiphyas postvittana (Lepidoptera: Tortricidae) by Dolichogenidea spp. (Hymenoptera: Braconidae) parasitoids. - Biocontrol Science and Technology 16: 1031-1042.

[12] Bernays, E.A. (1997): Feeding by lepidopteran larvae is dangerous. - Ecological Entomology 22: 121-123.

[13] Bernays, E.A., Bright, K.L., Gonzalez, N., Angel, J. (1994): Dietary mixing in a generalist herbivore: tests of two hypotheses. - Ecology 75: 1997-2006.

[14] Bernays, E.A., Mikenberg, O.P.J.M. (1997): Insect herbivores: different reasons for being a generalist. - Ecology 78: 1157-1169.

[15] Bezemer, T.M., Jones, T.H. (1998): Plant-insect herbivore interactions in elevated atmospheric $\mathrm{CO}_{2}$ : quantitative analyses and guild effects. - Oikos 82: 212-222.

[16] Bogacheva, I.A. (1986): Studies on the effects of different factors on population dynamics of phytophagous insects in the subarctic region, in Regulyatsiya chislennosti i plotnosti populyatsii zhivotnykh Subarktiki (Control over the Abundance and Population Density of Subarctic Animals), Sverdlovsk: Ural. - Otd. Akad. Nauk SSSR, 1986, pp. 1025.

[17] Bogacheva, I.A., Olschwang, V.N. (1978): Expansion of some Southern insect species to the forest-tundra, in Fauna, ekologiya i izmenchivost' zhivotnykh (Animal Fauna, Ecology and Variation), Sverdlovsk: Ural. - Otd. Akad. Nauk SSSR, 1978, pp. 16-18.

[18] Bolotov, I.N. (2004): Long-term changes in the fauna of diurnal Lepidopterans (Lepidoptera, Diurna) in the Northern Taiga subzone of the Western Russian Plain. Russian Journal of Ecology 35(2): 117-123.

[19] Brakefield, P.M. (1987): Geographical variability in, and temperature effects on, the phenology of Maniola jurtina and Pyronia tithonus (Lepidoptera, Satyrinae) in England and Wales. - Ecological Entomology 12: 139-148.

[20] Brakefield, P.M. (1984): The ecological genetics of quantitative characters of Maniola jurtina and other butterflies. - The Biology of Butterflies, Symposium of the Royal Entomological Society of London, 11 (ed. by Vane-Wright, R.I., Ackery, P.R.), pp. 167190. Academic Press, London. 
[21] Braschler, B., Hill, J.K. (2007): Role of larval host plants in the climate-driven range expansion of the butterfly Polygonia c-album. - Journal of Animal Ecology 76: 415-423.

[22] Bryant, S.R., Thomas, C.D., Bale, J.S. (1997): Nettle-feeding nymphalid butterflies: temperature, development and distribution. - Ecological Entomology 22: 390-398.

[23] Bryant, S.R., Thomas, C.D., Bale, J.S. (2000): Thermal ecology of gregarious and solitary nettle feeding nymphalid larvae. - Oecologica 122: 1-10.

[24] Buse, A., Good, J.E.G. (1996): Synchronization of larval emergence in winter moth (Operophtera brumata L.) and budburst in pedunculate oak (Quercus robur L.) under simulated climate change. - Ecological Entomology 21: 335-343.

[25] Buse, A., Good, J.E.G., Dury, S, Perrins, C.M. (1998): Effects of elevated temperature and carbon dioxide on the nutritional quality of leaves of oak (Quercus robur L.) as food for the Winter Moth (Operophtera brumata L.). - Functional Ecology 12: 742-749.

[26] Butterfield, J., Coulson, J.C. (1997): Terrestrial invertebrates and climate change: physiological and life-cycle adaptations. - In: Past and Future Rapid Environmental Changes (eds Huntley, B., Cramer, W., Morgan, A.W., Prentice, H.C., Allen, J.R.M.), pp. 401-412. Springer, Berlin.

[27] Butterfield, J. (1976): The response of development rate to temperature in the univoltine cranefly, Tipula subnodicornis Zetterstedt. - Oecologica 25: 89-100.

[28] Caputo, C., Rutitzky, M., Ballaré, C.L. (2006): Solar ultraviolet-B radiation alters the attractiveness of Arabidopsis plants to diamondback moths (Plutella xylostella L.): impacts on oviposition and involvement of the jasmonic acid pathway. - Oecologica 149(1): 81-90.

[29] Chen, I-C., Shiu, H-J., Benedick, S., Holloway, J.D., Chey, V.K., Barlow, H.S., Hill, J.K., Thomas, C.D. (2009): CElevation increases in moth assemblages over 42 years on a tropical mountain. - Proceedings of the National Academy of Sciences of the United States of America 106: 1479-1483.

[30] Chen, Y.H., Welter, S.C. (2007): Crop domestication creates a refuge from parasitism for a native moth. - Journal of Applied Ecology 44: 238-245.

[31] Connell, J.H. (1978): Diversity in tropical rain forests and coral reefs. - Science 199: $1302-1310$

[32] Conrad, K.F., Perry, J.N., Woiwod, I.P., Alexander, C.J. (2006a): Large-scale temporal changes in spatial pattern during declines of abundance and occupancy in a common moth. - Journal of Insect Conservation 1(10): 53-64.

[33] Conrad, K.F., Warren, M.S., Fox, R., Parsons, M.S., Woiwod, I.P. (2006b): Rapid declines of common, widespread British moths provide evidence of an insect biodiversity crisis. Biological Conservation 132: 279-291.

[34] Conrad, K.F., Woiwod, I.P., Parsons, M., et al. (2004): Long-term population trends in widespread British moths. - Journal of Insect Conservation 8: 119-136.

[35] Conrad, K.F., Woiwod, I.P., Perry, J.N (2002): Long-term decline in abundance and distribution of the garden tiger moth (Arctia caja) in Great Britain. - Biological Conservation 106: 329-337.

[36] Conrad, K.F., Woiwod, I.P., Perry, J.N (2003): East Atlantic teleconnection pattern and the decline of a common arctiid moth. - Global Change Biology 9(2): 125-130.

[37] Conrad, K.F., Perry, J.N., Woiwod, I.P. (2001): An abundance-occupancy time -lag during the decline of an arctiid tiger moth. - Ecology Letters 4: 300-303.

[38] Coope, G.R. (1970): Interpretations of Quaternary insect fossils. - Annual Review of Entomology 15: 97-120.

[39] Coope, G.R. (1987): Constancy of insect species versus inconstancy of Quaternary environments. - In: Diversity of Insect Faunas (eds: Mound L. A., Waloff N.), pp. 176187. Blackwell Scientific Publications, Oxford.

[40] Coope, G.R. (1995): The effect of Quaternary climate changes in insect populations: lessons from the past. - In: Insects in a changing environment (eds: Harrington, R., Stork, N.E.), pp. 30-48. Academic Press, San Diego. 
[41] Coulson, S.J., Hodkinson, I.D., Webb, N.R., Mikkola, K., Harrison, J.A., Pedgley, D.E. (2002): Aerial colonization of high Arctic islands by invertebrates: the diamondback moth Plutella xylostella (Lepidoptera: Yponomeutidae) as a potential indicator species. Diversity and Distributions 8: 327-334.

[42] Coulson, J.C., Horobin, J.C., Butterfield, J., Smith, G.R.J. (1976): The maintenance of annual life-cycles in two species of Tipulidae (Diptera); a field study relating to development, temperature and altitude. - Journal of Animal Ecology 45: 215-233.

[43] Coviella, C.E., Trumble, J.T. (1999): Effects of elevated atmospheric carbon dioxide on insect-plant interactions. - Conservation Biology 13: 700-712.

[44] Crawley, M.J. (1987): What makes a community invasible? - In: Colonization, Succession and Stability. The 26th Symposium of the British Ecological Society Held Jointly with the Linnean Society of London (eds Gray, A.J., Crawley, M.J., Edwards, P.J.), pp. 429-453. Blackwell Scientific Publications, Oxford.

[45] Danilevskii, A.S. (1965): Photoperiodism and Seasonal Development of Insects. - Oliver \& Boyd, Edinburgh.

[46] Davis, M.A., Grime, J.P., Thompson, K. (2000): Fluctuating resources in plant communities: a general theory of invasibility. - Journal of Ecology 88: 528-534.

[47] Davis, A.J., Jenkinson, L.S., Lawton, J.H., Shorrock,s B., Wood, S. (1998): Making mistakes when predicting shifts in species range in response to global warming. - Nature 391: 783-786.

[48] Dennis, R.L.H. (1993): Butterflies and Climate Change. Manchester: - Mancheste University Press.

[49] Dennis, R.L.H., Shreeve, T.G. (1991): Climatic change and the British butterfly fauna: opportunities and constraints. - BiologicalConservation 55: 1-16.

[50] Drégelyi-Kiss, Á., Drégelyi-Kiss, G., Hufnagel, L. (2008): Ecosystems as climate controllers - biotic feedbacks. - Applied Ecology and Environmental Research 6(2): 111134.

[51] Dury, S.J., Good, J.E.G., Perrins, C.M., Buse, A., Kaye, T. (1991): The effects of increasing $\mathrm{CO}_{2}$ and temperature on oak leaf palatability and the implications for herbivorous insects. - Global Change Biology 4: 55-62.

[52] Ehrlich, P.R. (1986): Which animal will invade? - In: Ecology of Biological Invasions of North America and Hawaii (eds Mooney, H.A., Drake, J.A.), pp. 79-95. Springer Verlag, New York, NY.

[53] Fajer, E.D., Bowers, M.D., Bazzaz, F.A. (1991): The effects of enriched $\mathrm{CO}_{2}$ atmosphere on the Buckeye butterfly, Junonia coenia. - Ecology 72: 751-754.

[54] Fajer, E.D., Bowers, M.D., Bazzaz, F.A. (1989): The effects of enriched carbon dioxide atmospheres on plant-insect herbivore interactions. - Science 243: 1198-1200.

[55] Fielding, R.A., Tatchell, G.M. (1995): Shifts in the flight periods of British aphids: a response to climate warming? - In: Insects in a Changing Environment (eds Harrington, R., Stork, N.E.), pp. 505-508. Academic Press, London.

[56] Fitter, A.H., Fitter, R.S.R. (2002): Rapid changes in flowering time in British plants. Science 296: 1689-1691.

[57] Fleming, R.A., Candau, J-N. (1998): Influences of climatic change on some ecological processes of an insect outbreak system in Canada's boreal forests and the implications for biodiversity. - Environmental Monitoring and assessment 49: 235-249.

[58] Fleming, R.A., Volney, W.J.A. (1995): Effects of climate change on insect defoliator population processes in Canada boreal forest - some plausible scenarios. - Water Air and Soil Pollution 82: 445-454.

[59] Foggo, A., Higgins, S., Wargent, J.J., Coleman, R.A. (2007): Tri-trophic consequences of UV-B exposure: plants, herbivores and parasitoids. - Oecologia 154(3): 505-512.

[60] Forister, M.L., Shapiro, A.M. (2003): Climatic trends and advancing spring flight of butterflies in lowland California. - Global Change Biology 9(7): 1130-1135. 
[61] Fox, R., Warren, M.S., Harding, P.T. et al. (2003): Butterflies for the new millennium: mapping butterfly distributions in Britain (Lepidoptera). - Proc. 13th Int. Coll. EIS, September 2001. pp. 79-86.

[62] Franzén, M., Johannesson, M. (2007): Predicting extinction risk of butterflies and moths (Macrolepidoptera) from distribution patterns and species characteristics. - Journal of Insect Conservation 11: 367-390.

[63] Gaston, K.J., Williams, P.H. (1996): Spatial patterns in taxonomic diversity. - In: Biodiversity (ed. Gaston. K.J.), pp. 202-229. Blackwell Science, Oxford.

[64] Goverde, M., Erhardt, A. (2003): Effects of elevated $\mathrm{CO}_{2}$ on the development and larval food-plant preference in the butterfly Coenonympha pamphilus (Lepidoptera, Satyridae). - Global Change Biology 9(1): 74-83.

[65] Gray, D.R. (1994): Gypsy moth development - a model of phenological events. - PhD dissertation. Virginia Polytechnic Institute and State University, Blacksburg, VA.

[66] Gray, D.R. (2008): The relationship between climate and outbreak characteristics of the spruce budworm in eastern Canada. - Climatic Change 87: 361-383.

[67] Grime, J.P. (1973): Competitive exclusion in herbaceous vegetation. - Nature 242: 344347.

[68] Gutierrez, A.P., Thibaud, D., Ellis, C.K., Ponti, L. (2006): Climatic limits of pink bollworm in Arizona and California: effects of climate warming. - Acta Oecologica 30: 353-364.

[69] Hamilton, J.G., Zangerl, A.R., Berenbaum, M.R., Pippen, J., Aldea, M., DeLucia, E.H. (2004): Insect herbivory in an intact forest understory under experimental $\mathrm{CO}_{2}$ enrichment. - Oecologia 138: 566-573.

[70] Hance, T., van Baaren, J., Vernon, P., Boivin, G. (2007): Impact of extreme temperatures on parasitoids in climate change perspective. - Annual Review of Entomology 52: 107126.

[71] Hanson, P.J., Weltzin, J.F. (2000): Drought disturbance from climate change: response of United States forests. - The Science of the Total Environment 262: 205-220.

[72] Harrington, R., Stork, N.E. (eds) (1995): Insects in a Changing Environment. $-17^{\text {th }}$ Symposium of the Royal Entomological Society. London, Academic Press.

[73] Harrington, R., Woiwod, I.P. (1995): Insect crop pests and the changing climate. Weather 50: 200-208.

[74] Hassell, M.P., Godfray, H.C., Comins, H.N. (1993): Effects of global change on the dynamics of insect host-parasitoid interactions. - In: Kareiva, P.M., Kingsolver, J.G., Huey, R.B. (editors), Biotic interactions and global change. Sinauer Associates Inc., Sunderland, MA, pp. 402-423.

[75] Hatcher, P.E., Paul, N.D. (1994): The effect of elevated UV-B radiation on herbivory of pea by Autographa gamma. - Entomologica Experimentalis et Applicata 71: 227-233.

[76] Hedden, R.L. (1989): Global climate change: implications for silviculture and pest management. - The Station 74: 555-562.

[77] Heinrich, B. (1977): Why have some animals evolved to regulate high body temperature? - American Naturalist 111: 623-640.

[78] Hellmann, J.J., Pelini, S.L., Prior, K.M., Dzurisin, J.D.K. (2008): The response of two butterfly species to climatic variation at the edge of their range and the implications for poleward range shifts. - Oecologica 157: 583-592.

[79] Hickling, R., Roy, D.B., Hill, J.K., Fox, R., Thomas, C.D. (2006): The distributions of a wide range of taxonomic groups are expanding polewards. - Global Change Biology 12: 450-455.

[80] Hilker, F.M, Westerhoff, F.H. (2007): Preventing extinction and outbreaks in chaotic populations. - Am Nat. 170: 232-241.

[81] Hill, J.K., Thomas, C.D., Huntley, B. (1999): Climate and habitat availability determine 20th century changes in a butterfly's range margin. - Proceedings of the Royal Society of London Series B. Biological Sciences 266: 1197-1206. 
[82] Hill, J.K., Thomas, C.D., Fox, R., Telfer, M.G., Willis, S.G., Asher, J., Huntley, B. (2002): Responses of buterflies to twentieth century climate warming: implications for future ranges. - Proceedings of the Royal Society of London Series B. Biological Sciences 269: 2163-2171.

[83] Hochuli, D.F. (1996): The ecology of plant/insect interactions: implications of digestive strategy for feeding by phytophagous insects. - Oikos 75: 133-141.

[84] Hódar, J.A., Zamora, R. (2004): Herbivory and climatic warming: a Mediterranean outbreaking caterpillar attacks a relict, boreal pine species. - Biodiversity and Conservation 13: 493-500.

[85] Hodkinson, I.D. (1999): Species response to global environmental change or why ecophysiological models are important: a reply to Davis et al. - Journal of Animal Ecology 68: 1259-1262.

[86] Horn, H. (1975): Markovian properties of forest succession. - In: Ecology and evolution of communities (eds: Cody, M.L., Diamond, J.M.), pp. 196-211, Belknap Öress, Cambridge, Massachusetts.

[87] Hunter, A.F., Elkinton, J.S. (2000): Effects of synchrony with host plant on populations of a spring-feeding lepidopteran. - Ecology 81: 1248-1261.

[88] IPCC - Intergovernmental Panel on Climate Change (1990): IPCC First Assessment Report. http://www.ipcc.ch/ipccreports/far/wg_I/ipcc_far_wg_I_full_report.pdf

[89] IPCC - Intergovernmental Panel on Climate Change (1995): IPCC Second Assessment Report. $\quad \mathrm{http}: / / w w w . i p c c . c h / p d f / c l i m a t e-c h a n g e s-1995 / i p c c-2 n d-a s s e s s m e n t / 2 n d$ assessment-en.pdf

[90] IPCC - Intergovernmental Panel on Climate Change (2001): IPCC Third Assessment Report. http://www.grida.no/publications/other/ipcc tar/

[91] IPCC - Intergovernmental Panel on Climate Change (2007): IPCC Fourth Assessment Report.

http://www.ipcc.ch/publications_and_data/publications_ipcc_fourth_assessment_report_s ynthesis_report.htm

[92] Isakov, V.N., Gromov, I.A. (1997): Diurnal Butterflies (Lepidoptera, Rhopalocera) of the Northwestern Part of Murmansk Oblast, Entomol. - Obozr. 1: 122-126.

[93] Johns, C.V., Hughes, L. (2002): Interactive effects of elevated $\mathrm{CO}_{2}$ and temperature on the leaf-miner Dialectica scalariella Zeller (Lepidoptera: Gracillariidae) in Paterson's Curse, Echium plantagineum (Boraginaceae). - Global Change Biology 8: 142-52.

[94] Karsholt, O., Razowski, J. (1996): The Lepidoptera of Europe. - A distributional checklist. Apollo Books, Stenstrup.

[95] Kearney, M., Porter, W.P., Williams, C., Ritchie, S., Hoffmann, A.A. (2009): Integrating biophysical models and evolutionary theory to predict climatic impacts on species' ranges: the dengue mosquito Aedes aegypti in Australia. - Func Ecol. 23: 528-538.

[96] Kearney, M.R., Briscoe, N.J., Karoly, D.J., Porter, W.P., Norgate, M., Sunnucks, P. (2010): Early emergence in a butterfly causally linked to anthropogenic warming. Biology Letters 2010. Jun. 7. (Epub ahead of print).

[97] Kerr, J.T. (2001): Butterfly species richness patterns in Canada: energy, heterogeneity and the potential consequences of climate change. - Conservation Ecology 5: 10-19.

[98] Kingsolver, J.G. (1989): Weather and the population dynamics of insects: integrated physiological and population ecology. - Physiological Zoology 62: 314-334.

[99] Kiritani, K. (2006): Predicting impacts of global warming on population dynamics and distribution of arthropods in Japan. - Population Ecology 48: 5-12.

[100] Knepp, R.G., Hamilton, J.G., Mohan, J.E., Zangerl, A.R., Berenbaum, M.R., DeLucia, E.H. (2005): Elevated $\mathrm{CO}_{2}$ reduces leaf damage by insect herbivores in a forest community. - New Phytologist 167(1): 207-218.

[101] Kuchlein, J.H., Donner, J.H. (1993): De kleine vlinders; handboek voor de faunistiek van de Nederlandse Microlepidoptera. - Wageningen, Pudoc. 
[102] Kuchlein, J.H., Ellis, W.N. (1997): Climate-induced changes in the microlepidoptera fauna of the Netherlands and the implications for nature conservation. - Journal of Insect Conservation 1: 73-80.

[103] Kulfan, J., Zach, P. (2004): Spolocenstvá motylov na smreku obycajnom (Picea abies) pozdlz vertikálneho gradientu v Skálnatej doline. - Stúdia TANAP 7(40): 311-319.

[104] Ladányi, M., Horváth, L. (2010): A review of the potential climate change impact on insect populations - general and agricultural aspects. - Applied Ecology and Environmental Research 8(2): 143-152.

[105] Lawton, J.H. (1995): The response of insects to environmental change. - In: Insects in a Changing Environment (eds: Harrington, R., Stork, R.E.) pp. 3-26. London: Academic Press.

[106] Lawton, J.H. (1998): Small earthquakes in Chile and climatic change. - Oikos 82: 209211.

[107] Lawton, J.H., Brown, K.C. (1986): The population and community ecology of invading insects. - Philosophical Transactions of the Royal Society London B, 314: 607-617.

[108] Lawton, J.H., McNeill, S. (1979): Between the devil and deep blue sea: on the problem of being a herbivore. - In: Population Dynamics (eds Anderson, R.M., Turner, B.D., Taylor, L.R.), pp. 223-244. Blackwell Scientific publications, Oxford.

[109] Leather, S.R., Walters, K.F.A., Bale, J.S. (1993): The Ecology of Insect Overwintering. Cambridge University Press, Cambridge.

[110] Legaspi, B.C., Legaspi, J.C. (2010): Field-level validation of a CLIMEX model for Cactoblastis cactorum (Lepidoptera: Pyralidae) using estimated larval growth rates. Environmental Entomology 39(2): 368-377.

[111] Lincoln, D.E., Couvet, D. (1989): The effect of carbon supply on allocation to allelochemicals and caterpillar consumption of peppermint. - Oecologica 78: 112-114.

[112] Lincoln, D.E., Couvet, D., Sionit, N. (1986): Response of an insect herbivore to host plants grown in carbon dioxide enriched atmospheres. - Oecologica 69: 556-560.

[113] Lincoln, D.E., Fajer, E.D., Johnson, R.H. (1993): Plant-insect herbivore interactions in elevated $\mathrm{CO}_{2}$ environments. - Trends in Ecology and Evolution 8: 64-68.

[114] Lincoln, D.E., Sionit, N., Strain, B.R. (1984): Growth and feeding response of Pseudoplusia includens (Lepidoptera: Noctuidae) to host plants grown in controlled carbon dioxide atmospheres. - Environmental Entomology 13(6): 1527-1530.

[115] Lindroth, R.L., Kinney, K.K., Platz, C.L. (1993): Responses of deciduous trees to elevated atmospheric $\mathrm{CO}_{2}$ : productivity, phytochemistry and insect performance. Ecology 74: 763-777.

[116] Lloyd, J., Farquhar, G.D. (1996): The $\mathrm{CO}_{2}$ dependence of photosynthesis, plant growth responses to elevated atmospheric $\mathrm{CO}_{2}$ concentrations and their interaction with soil nutrient status. 1. General principles and forest ecosystems. - Functional Ecology 10: 432.

[117] Lockwood, J.L., Cassey, P., Blackburn, T. (2005): The role of propagule pressure in explaining species invasions. - Trends in Ecology and Evolution 20: 223-228.

[118] Logan, J.A., Régniere, J., Powell, J.A. (2003): Assessing the impacts of global warming on forest pest dynamics. - Frontiers in Ecology and the Environment 1: 130-137.

[119] Logan, J.A., Wollkind, D.J., Hoyt, S.C., Tanigoshi, L.K. (1976): An analytical model for description of temperature dependent rate phenomena in arthropods. - Environmental Entomology 5: 1133-1140.

[120] Lysyk, T.J. (1989): Stochastic model of eastern spruce budworm (Lepidoptera: Torticidae) phenology on white spruce and balsam fir. - Journal of Economical Entomology 82: 1161-1168.

[121] Martinat, P.J. (1987): The role of climatic variation and weather forecast in forest insect outbreaks. - In: Barbosa P. et al. (eds): Insect outbreaks. Academic Press, San Diego. Pp. 241-268. 
[122] Mattson, W.J., Haack, R.A. (1987): The role of drought in outbreaks of plant-eating insects. - BioScience 37: 110-118.

[123] May, M.L. (1976): Insect thermoregulation. - Annual Review of Entomology 24: 313349.

[124] McCloud, E.S., Berenbaum, M.R. (1994): Stratospheric ozone depletion and plant-insect interactions: effects of UVB radiation on foliage quality of Citrus jambhiri for Trichoplusia ni. - Journal of Chemical Ecology 20: 525-539.

[125] McGavin (1994): Quaternary insects and their environments. - Nature 370: 261-262.

[126] McNeill, S., Southwood, T.R.E. (1978): The role of nitrogen in the development of insect/plant relationships. - In: Biochemical Aspects of Plant and Animal Coevolution (ed. Harborne, J.B.), pp. 77-98. Academic Press, London.

[127] Memmott, J., Craze, P.G., Harman, H.M., Syrett, P., Fowler, S.V. (2005): The effect of propagule size on the invasion of an alien insect. - Journal of Animal Ecology 74: 50-62.

[128] Mitikka, V., Heikkinen, R.K., Luoto, M., Araújo, M.B., Saarinen, K., Pöyry, J., Fronzek, S. (2008): Predicting range expansion of the map butterfly in Northern Europe using biclimatic models. - Biodiversity and Conservation 17: 623-641.

[129] Mo, J., Trevino, M., Palmer, W.A. (2000): Establishment and distribution of the rubber vine moth, Euclasta whalleyi Popescu-Gorj and Constantinescu (Lepidoptera: Pyralidae), following its release in Australia. - Australian Journal of Entomology 39: 344-350.

[130] Morimoto, N., Imura, O., Kiura, T. (1998): Potential effects of global warming on the occurrence of Japanese pest insects. - Applied Entomology \& Zoology 33(1): 147-155.

[131] Murphy, J.M (1995): Transient response of the Hadley Centre coupled ocean-atmosphere model to increasing carbon dioxide. Part I: Control climate and flux adjustment. - J. of Clim. 8: 36-56.

[132] Niemela, P., Mattson, W.J. (1996): Invasion of North American forests by European phytophagous insects. Legacy of the European crucible? - BioScience 46: 741-753.

[133] Nylin, S., Nygren, G.H., Söderlind, L., Stefanescu, C. (2008): Geographical variation in host plant utilization in the comma butterfly: the roles of time constraints and plant phenology. - Evolutionary Ecology 23(5): 807-825.

[134] Olschwang, V.N. (1992): Struktura i dinamika naseleniya nasekomykh Yuzhnogo Yamala (The Structure and Dynamics of the Insect Fauna in Southern Yamal). Yekaterinburg, Nauka, 1992.

[135] Palmer, W.A., Lockett, C.J., Senaratne, K.A.D.W., McLennan, A. (2007): The introduction and release of Chiasmia inconspicua and C. assimilis (Lepidoptera: Geometridae) for the biological control of Acacia nilotica in Australia. - Biological Control 41: 368-378.

[136] Panigaj, L., Panigaj, M. (2008): Changes in Lepidopteran assemblages in Temnosmreciská dolina valley (the High Tatra Mts, Slovakia) over the last 55 years. Biologia 63(4): 582-587.

[137] Pannekoek, J., Van Strien, A.J. (2001): Trim 3 Manual (Trends \& Indices for Monitoring data). - Statistics Netherlands, Voorburg.

[138] Parmesan, C. (1996): Climate and species' range. - Nature 382: 765-6.

[139] Parmesan, C., Yohe, G. (2003): A globally coherent fingerprint of climate change impacts across natural systems. - Nature 421: 37-43.

[140] Parmesan, C. (2006): Ecological and evolutionary responses to recent climate change. Annual Review of Ecology, Evolution and Systematics 37: 637-669.

[141] Parmesan, C., Ryrholm, N., Stefanescu, C., Hill, J.K., Thomas, C.D., Descimon, H., Huntley, B., Kaila, L., Kullberg, J., Tammaru, T., Tennent, W.J., Thomas, J.A., Warren, M. (1999): Poleward shifts in geographical ranges of butterfly species associated with regional warming. - Nature 399: 579-583.

[142] Pearson, D.E., Callaway, R.M. (2003): Indirect effects of host-specific biological control agents. - Trends in Ecology and Evolution 18: 456-461. 
[143] Pearson, R.G., Dawson, T.P. (2003): Predicting the impacts of climate change on the distribution of species: are bioclimate envelope models useful? - Global Ecology \& Biogeography 12: 361-371.

[144] Peters, R.L. (1990): Effects of global warming on forests. - Forest Ecology and Management 35: 13-33.

[145] Petrányi, G., Hufnagel, L., Horváth, L. (2007): A klímaváltozás és a biodiverzitás kapcsolata - földrajzi analógiai esettanulmány az európai lepkefaunára - „KLÍMA-21” Füzetek 50: 62-69.

[146] Pimentel, D. (2002): Non-native invasive species of arthropods and plant pathogens in the British Isles. - In: Biological Invasions. Economic and Environmental Costs of Alien plant, Animal and Microbe Species (ed. Pimentel, D), pp. 151-155. CRC Press, Boca Raton, FL.

[147] Pollard, E., Yates, T.J. (1993): Monitoring Butterflies for Ecology and Conservation. Chapman \& Hall, London.

[148] Pollard, E., Moss, D., Yates, T.J. (1995): Population trends of common British butterflies at monitored sites. - Journal of Applied Ecology 32: 9-16.

[149] Pollard, E., Greatorey-Davies, J.N., Thomas, J.A. (1997): Drought reduces breeding success of the butterfly Aglais urticae. - Ecological Entomology 22: 315-318.

[150] Porter, J.H., Parry, M.L., Carter, T.R. (1991): The potential effects of climatic change on agricultural insect pests. - Agric. Forest. Meteorol. 57: 221-240.

[151] Porter, K. (1982): Basking behaviour in larvae of the butterfly Euphydryas aurinia. Oikos 38: 308-312.

[152] Pullin, A.S., Bale, J.S. (1989): Effects of low temperature on diapausing Aglais urticae and Inachis io (Lepidoptera: Nymphalidae): cold hardiness and overwintering survival. Journal of Insect Physiology 35: 277-281.

[153] Roberts, E.A., Ravlin, F.W., Fleischer, S.J. (1993): Spatial data representation for integrated pest management programs. - American Entomologist 39: 92-108.

[154] Ronkay, L. (2004): Jelenkori faunaváltozások a Kárpát-medence belső területein: tények, jelenségek és értékelhetőségük. (Lepkék, elsősorban Macroheterocera) - Esettanulmány „A globális klímaváltozás hatásai Magyarország faunájára” c. kérdéskörröl. Kézirat, 22 p.

[155] Rotschild, M. (2000): The garden tiger moth - a delightful chemist. - Butterfly Conservation News 75: 26-28.

[156] Roxburgh, S.H., Shea, K., Wilson, J.B. (2004): The intermediate disturbance hypothesis: Patch dynamics and mechanisms of species coexistence. - Ecology 85(2): 359-371.

[157] Roy, D.B., Sparks, T.H. (2000): Phenology of British butterflies and climate change. Global Change Biology 6: 407-416.

[158] Roy, D.B., Rothery, P., Moss, D., Pollard, E., Thomas, J.A. (2001): Butterfly numbers and weather: predicting historical trends in abundance and the future effects of climate change. - Journal of Animal Ecology 70: 201-217.

[159] Saarinen, K., Lahti, T., Marttila, O. (2003): Population trends of Finnish butterflies (Lepidoptera: Hesperioidea, Papilionoidea) in 1991-2000. - Biodiversity and Conservation 12: 2147-2159.

[160] Salama, N.K.G., Knowler, J.T., Adams, C.E. (2007): Increasing abundance and diversity in the month assemblage of east Loch Lomondside, Scotland over a 35 year period. Journal of Insect Conservation 11: 151-156.

[161] Sanders, C.J., Wallace, D.R., Lucuik, G.S. (1978): Flight activity of female eastern spruce budworm (Lepidoptera: Torticidae) at constant temperatures in the laboratory. Canadian Entomology 107: 1289-1299.

[162] Simberloff, D. (1989): Which insect introductions succeed and which fail? - In: Biological Invasions: A Global Perspective (eds Drake, J.A. et al.), pp. 61-75. John Wiley \& Sons Ltd., New York. 
[163] Slansky, F. (1993): Nutritional ecology: the fundamental quest for nutrients. Caterpillars: Ecological and Evolutionary Constraints on Foraging. - (eds Stamp, N.E., Casey, T.M.), pp. 29-91. Chapman \& Hall, New York.

[164] Sparks, T.H., Carey, P.D., Combes, J. (1997): First leafing dates of trees in Surrey between 1947 and 1996. - The London Naturalist 76: 15-20.

[165] Sparks, T.H., Jeffree, E.P., Jeffree, C.E. (2000): An examination of the relationship between flowering times and temperature at the national scale using long-term phenological records from the UK. International Journal of Biometeorology 44: 82-87.

[166] Spencer, J.L., Hibbard, B.E., Moeser, M., Onstad, D. (2009): Behaviour and ecology of the western corn rootworm Diabrotica virgifera virgifera LeConte - Agric. For. Entomology 11: 9-27.

[167] Stange, G. (1997): Effects of changes in atmospheric carbon dioxide on the location of hosts by the moth, Cactoblastis cactorum. - Oecologia 110: 539-545.

[168] Stefanescu, C., Penuelas, J., Filella, I. (2003): Effects of climatic change on the phenology of butterflies in the Northwest Mediterranean Basin. - Global Change Biology 9(10): 1494-1506

[169] Stigter, H., Frankenhuyzen, A. van (1991): Phyllonoricter leucographella, een voor Nederland nieuwe bladmineerder (Lepidoptera: Gracillariidae). - Entomologische Berichten, Amsterdam 51: 129-135.

[170] Stiling, P., Cornelissen, T. (2007): How does elevated carbon dioxide $\left(\mathrm{CO}_{2}\right)$ affect plantherbivore interactions? A field experiment and meta-analysis of $\mathrm{CO}_{2}$-mediated changes on plant chemistry and herbivore performance. - Global Change Biology 13(9): 18231842.

[171] Stireman, J.O., Dyer, L.A., Janzen, D.H., Singer, M.S., Lill, J.T., Marquis, R.J., Ricklets, R.E., Gentry, G.L., Hallwachs, W., Coley, P.D., Barone, J.A., Greeney, H.F., Connahs, H., Barbosa, P., Morais, H.C., Diniz, I.R. (2005): Climatic unpredictability and parasitism of caterpillars: implications of global warming. - Proceedings of the National Academy of Science 102: 17384-17387.

[172] Strand, J.F. (2000): Some agrometeorological aspects of pest and disease management for the 21st century. - Agricultural and Forest Meteorology 103(1-2): 73-82.

[173] Takken, W., Knolsm, G.J. (2007): Emerging pests and vector-borne diseases in Europe: ecology and control of vector-borne diseases. - Netherlands, Wageningen Academic Publishers, 500p.

[174] Thomas, C.D., Bodsworth, E.J., Wilson, R.J., Simmons, A.D., Davies, Z.G., Musche, M., Conradt, L. (2001): Ecological and evolutionary processes at expanding range margins. Nature 411: 577-581.

[175] Thomas, C.D., Cameron, A., Green, R.E., Bakkenes, M., Beaumont, L.J., Collingham, Y.C., Erasmus, B.F.N., de Siqueira, M.F., Grainger, A., Hannah, L., Hughes, L., Huntley, B., van Jaarsveld, A.S., Migley, G.F., Miles, L., Ortega-Huerta, M.A., Peterson, A.T., Phillips, O.L., Williams, S.E. (2004a): Extinction risk from climate change. - Nature 427: 145-148.

[176] Thomas, J.A., Telfer, M.G., Roy, D.B. (2004b): Comparative losses of British butterflies, birds and plants and the global extinction crisis. - Science 303: 1879-1881.

[177] Thomson, L.J., Macfadyen, S., Hoffmann, A.A. (2010): Predicting the effects of climate change on natural enemies of agricultural pests. - Biological Control 52: 296-306.

[178] Tobin, P.C., Nagarkatti, S., Loeb, G., Saunders, M.C. (2008): Historical and projected interactions between climate change and insect voltinism in a multivoltine species. Global Change Biology 14: 951-957.

[179] Traw, M.B., Lindroth, R.L., Bazzaz, F.A. (1996): Decline in gypsy moth (Lymantria dispar) performance in an elevated $\mathrm{CO}_{2}$ atmosphere depends upon host plant species. Oecologica 108: 113-120.

[180] Uniyal, S.K., Uniyal, A. (2009): Climate change and large-scale degradation of spruce: common pattern across the globe. - Clim. Res. 38: 261-263. 
[181] Uvarov, B.P. (1931): Insects and climate. - Transactions of the Entomological Society. London 79: 1-247.

[182] Van Strien, A.J., Pannekoek, J., Gibbons, D.W. (2001): Indexing European bird population trends using results of national monitoring schemes: a trial of a new method. Bird Study 48: 200-213.

[183] Venette, R.C., Hutchison, W.D. (1999): Assessing the risk of establishment by pink bollworm (Lepidoptera: Gelechiidae) in the Southeastern United States. - Environmental Entomology 28: 445-455.

[184] Visser, M.E., Holleman, I.J.M. (2001): Warmer springs disrupt the synchrony of oak and winter moth phenology. - Proceedings of the Royal Society of Biological Sciences 268: 289-294.

[185] Visser, M.E., van Noordwijk, A.J., Tinbergen, J.M., Lessels, C.M. (1998): Warmer springs lead to mistimed reproduction in great tits (Parus major). - Proceedings of the Royal Society of Biological Sciences 265: 1867-1870.

[186] Volney, W.J.A., Fleming, R.A. (2000): Climate change and impacts of boreal forest insects. - Agricultural Ecosystems and Environment 82: 283-294.

[187] Vos, R. de, Zumkehr, P.J. (1995): De verspreiding van Omphaloscelis lunosa in Nederland (Lepidoptera: Noctuidae). - Entomologische berichten, Amsterdam, 55, 16973.

[188] Walther, G.R., Post, E., Convey, P., Menzel, A., Parmesan, C., Beebee, T.J.C., Fromentin, J.M., Hoegh-Guldberg, O., Bairlein, F. (2002): Ecological responses to recent climate change. - Nature 416: 389-395.

[189] Ward, N.L., Masters, G.J. (2007): Linking climate change and species invasion: an illustration using insect herbivores. - Global Change Biology 13: 1605-1615.

[190] Waring, P. (2000): Wildlife reports: moths. - British Wildlife: 57-58.

[191] Warren, M.S., Hill, J.K., Thomas, J.A., Asher, J., Fox, R., Huntley, B., Roy, D.B., Telfer, M.G., Jeffcoate, S., Harding, P., Jeffcoate, G., Willis, S.G., Greatorex-Davies, J.N., Moss, D., Thomas, C.D. (2001): Rapid response of British butterflies to opposing forces of climate and habitat change. - Nature 414(6859): 65-69.

[192] Watt, A.D., Woiwod, I.P. (1997): The effect of phenological asynchrony on population dynamics: analysis of fluctuations of British Macrolepidoptera. - Oikos 87: 411-416.

[193] Watt, A.D., Ward, L.K., Eversham, B.C. (1990): Effects on animals: Invertebrate. - In: The greenhouse effect and terrestrial ecosystems of the UK, (eds: Cannel, M.G.R., Hooper, M.D.) ITE Research Publication no. 4., Institute of Terrestrial Ecology, London. Pp. 32-37.

[194] Wilf, P., Labandeira, C.C. (1999): Response of plant-insect associations to PaleoceneEocene warming. - Science 284: 2153-2156.

[195] Williams, D.W., Liebhold, A.M. (1995): Forest defoliators and climatic change: Potential changes in spatial distribution of outbreaks of western spruce budworm (Lepidoptera: Tortricidae) and gypsy moth (Lepidoptera: Lymantriidae). - Environmental Entomology 24: 2-9.

[196] Wilson, R.J., Gutiérrez, D., Gutiérrez, J., Martínez, D., Agudo, R., Monserrat, V.J. (2005): Changes to elevational limits and extent of species' ranges associated with climate change. - Ecology Letters 8: 1138-1146.

[197] Whittaker, J.B. (2005): Impacts and responses at population level of herbivorous insects to elevated $\mathrm{CO}_{2}$. - European Journal of Entomology 96: 149-156.

[198] Woiwod, I.P (1997): Detecting the effects of climate change on Lepidoptera. - Journal of Insect Conservation 1: 149-158.

[199] Woiwod, I.P (1991): The ecological importance of long-term synoptic monitoring. - In: The Ecology of Temperate Cereal Fields, (Firbank, L.G., Carter, N., Darbyshire, J.F., Potts, G.R. eds) pp. 275-304. Oxford: Blackwell.

[200] Woodward, F.I. (1992): Tansley review no. 41. Predicting plant responses to global environmental change. - New Phytologist 122: 239-251. 
[201] Yamamura, K., Kiritani, K. (1998): A simple method to estimate the potential increase in the number of generations under global warming in temperate zones. - Applied Entomology \& Zoology 33(2): 289-298.

[202] Zalucki, M.P., Furlong, M.J. (2005): Forecasting Helicoverpa populations in Australia: A comparison of regression based models and a bioclimatic based modelling approach. Insect Science 12: 45-56.

[203] Zhou, X., Harrington, R., Woiwod, I.P., Perry, J.N., Clark, S.J., Bale, S.J. (1996): Impact of climate change on aphid flight phenology. - Aspetcs of Applied Biology 45: 299-305. 